\title{
TRADE OF THE GERMAN PROTECTORATES
}

As the last of the European Powers Germany has entered the colonial arena. Since the year 1884 it acquired by treaties with native chiefs and the Powers, interested in Africa and the Pacific, nine Protectorates covering together no less than $26,000,00 \mathrm{sq} . \mathrm{km}$. The largest of these Protectorates are the four African Possessions : TOGO, Kamerun, DeUtSch SUED West AFriCA, and DEUTSCH OST AFrICA. Next in importance come the colonies in the Pacific: DeUtsch NeU GUINEA, Karolinen, Marianen, Palau, Samoa, Marshallinseln. The smallest is the Chinese Protectorate of KrautschoU. When Germany acquired these colonies, their value from a trading point was almost nil, whilst hardly any attempt had been made to develop their natural resources. Ost Africa was regarded by the Arab traders only as a hunting ground for elephants and slaves. Owing to interior wars and famines its population was too poor to buy from the civilised world anything but beads, powder, guns and spirits. Togo and Kamerun were valuable only as markets for bad spirits. Their exports consisted entirely of small quantities of palm kernels and palm oil. Sued West Africa was considered to be so barren and hopeless that neither the Cape Colony nor the English Government would incur the obligation of maintaining order and peace there. Trade was almost unknown. Of what little importance the German Possessions in the Pacific were up to a very recent date is no less well known. Under these circumstances it is not surprising to see, that the trade of these Protectorates is still little 
developed and very small if compared with that of neighbouring older colonies. The value of the exports and imports of all German colonies was in 1899 , the last year for which complete statistics are published, $52,043,200 \mathrm{M} .=£ 2,602,160$. This shows great progress, if we compare the figures of the last eight years for which the trade statistics are available.

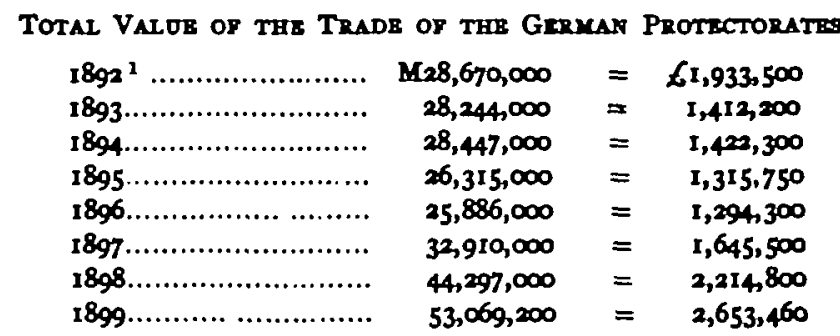

A great part of the exports of the Protectorates go to foreign markets, and a great deal of the merchandise imported there comes from foreign countries, which enjoy in every respect the same treatment and the same advantages as the mother country.

The part taken by Germany in the trade of its Protectorates is shown in the following table:-

\begin{tabular}{|c|c|c|c|}
\hline 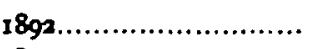 & Mio, 331, & $=$ & $\measuredangle 516,550$ \\
\hline $1893 \ldots \ldots \ldots$ & $10,227,000$ & $=$ & 511,350 \\
\hline 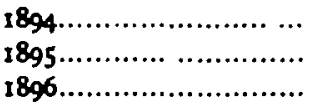 & $\begin{array}{r}10,270,000 \\
8,975,000 \\
11,348,000\end{array}$ & $\begin{array}{l}= \\
=\end{array}$ & $\begin{array}{l}513,500 \\
448,750 \\
567,400\end{array}$ \\
\hline 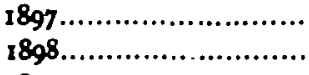 & $\begin{array}{l}14,245,000 \\
16,868,000\end{array}$ & $=$ & $\begin{array}{l}712,250 \\
843,400\end{array}$ \\
\hline 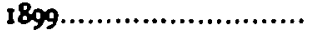 & $20,809, \infty \infty$ & $=$ & $1,040,450$ \\
\hline
\end{tabular}

The trade of the different German Protectorates has taken a somewhat irregular development : internal wars, failures of crops, and other obstacles baving exercised for some time a pernicious influence. Nevertheless the statistics prove in general a not unfavourable continual progress of export and import trade for the eight years in question, as will be shown in the following figures :-

1 Fins year for which complete statiatios have been published. 
Trede of the Gerenay Protectorater.

Deutscr Ost Africa (Greman Enst Africa):

\begin{tabular}{|c|c|c|c|c|c|c|}
\hline I & & $\begin{array}{l}\text { Imports from } \\
M 8,054, \infty 00\end{array}$ & and & $\begin{array}{l}\text { Exports to } \\
\mathbf{M}_{7}, \infty 9,5,500\end{array}$ & \multicolumn{2}{|c|}{$\begin{array}{l}\text { Foreign Countries } \\
\ldots \ldots \ldots \ldots M_{5}, 083,500\end{array}$} \\
\hline & $\ldots$ & $7,712,800$ & & $5,5^{80,700}$ & ............. & $13,493,600$ \\
\hline & .... & $7,167,700$ & .................. & $4,877,000$ & ............. & $12,044,700$ \\
\hline & $\ldots .$. & $7,608,500$ & ................ & $3,257,600$ & . & $10,866,100$ \\
\hline I & ... & $8,665,000$ & ........... & $4,117,100$ & …….... & $12,782,100$ \\
\hline 1897 & $\ldots$ & $9,042,100$ & …........... & $4,958,500$ & ...... & $13,980,600$ \\
\hline & & $11,852,700$ & …........... & $4,532,900$ & ..... & 85,60 \\
\hline 1899 & .... & $10,822,600$ & .............. & $3,957,100$ & .............. & $14,759,700$ \\
\hline
\end{tabular}

Kamenos :

\begin{tabular}{|c|c|c|c|c|c|c|}
\hline 1892 & ... & $\mathrm{M} 4,470,800$ & & $14,263,800$ & $\cdots$ & M8,734,600 \\
\hline 1893 & & $4,761,600$ & & $4,633,400$ & ….............. & $8,795, \infty 00$ \\
\hline $\begin{array}{l}1894 \\
1895\end{array}$ & ...... & $\begin{array}{l}6,197,400 \\
5,658,200\end{array}$ & & $\begin{array}{l}4,455,300^{\circ} \\
4,089,800\end{array}$ & $\begin{array}{l}\text { ………... } \\
\text { ……....... }\end{array}$ & $\begin{array}{r}10,952,700 \\
9,748,000\end{array}$ \\
\hline 1896 & ....... & $5,358,900$ & & $3,961,300$ & ….......... & $9,320,200$ \\
\hline 189 & $\cdots$ & $6,326,800$ & $\cdots$ & $3,385,500$ & ................. & $9,712,300$ \\
\hline & ... & $9,96,800$ & & $4,601,600$ & ................ & $13,898,400$ \\
\hline 189 & & $11,133,200$ & 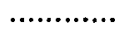 & $4,840,800$ & ….......... & $15,974, \infty 00$ \\
\hline
\end{tabular}

Tooo:

\begin{tabular}{|c|c|c|c|c|c|c|}
\hline 1892 & & $M_{2}, 135,900$ & ... & $(2,411,500$ & & M4,547,400 \\
\hline 1893 & .... & $2,414,900$ & …............ & $3,413,900$ & ............... & $5,828,80$ \\
\hline 189 & $\cdots$ & $2,240,600$ & ................... & $2,894,400$ & ….............. & $5,135, \infty 00$ \\
\hline $\begin{array}{l}1895 \\
1896\end{array}$ & ..... & $\begin{array}{l}2,353,300 \\
1,886,800\end{array}$ & …....... & $\begin{array}{l}3,048,500 \\
1,651,400\end{array}$ & …......... & $\begin{array}{l}5,401,800 \\
3,538,200\end{array}$ \\
\hline 7897 & .... & $1,975,900$ & $\ldots \ldots \ldots \ldots$ & $771, \infty \infty$ & ............ & $2,746,900$ \\
\hline 189 & $\ldots$ & $2,490,900$ & ...... & $1,470,484$ & ............. & $3,961,400$ \\
\hline 189 & & $3,279,700$ & ....... & $2,582,700$ & ....... & $5,862,400$ \\
\hline
\end{tabular}

Sukd West Arrica :

$\begin{array}{rrrrrrr}1897 & 1 \\ 1 & \ldots . . & M 4,887,300 & \ldots \ldots \ldots \ldots . M 1,246,700 & \ldots \ldots \ldots . & M 6,134,000 \\ 1898 & \ldots \ldots & 5,868,200 & \ldots \ldots \ldots \ldots & 915,800 & \ldots \ldots \ldots \ldots & 6,785,000 \\ 1899 & \ldots \ldots & 8,941,200 & \ldots \ldots \ldots \ldots . & 1,399,500 & \ldots \ldots \ldots \ldots . & 10,340,700\end{array}$

DeUtsch Neo GoINEA, ETc. : 2

\begin{tabular}{|c|c|c|c|c|c|}
\hline $\begin{array}{l}1890 \ldots . \\
1893 \ldots \ldots\end{array}$ & $\begin{array}{r}\text { Mi51, } \infty 00 \\
251, \infty 00\end{array}$ & ……… & $\begin{array}{r}M_{154, \infty}, 00 \\
36,000\end{array}$ & 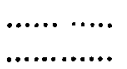 & $\begin{array}{r}\text { M305,000 } \\
267,000\end{array}$ \\
\hline $394 \ldots . .$. & $259, \infty 00$ & ............. & 470,000 & …......... & $729, \infty 00$ \\
\hline $\begin{array}{lll}1895 & \ldots \ldots \\
1896 & \ldots \ldots\end{array}$ & $\begin{array}{l}144,000 \\
283,000\end{array}$ & 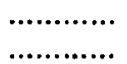 & $\begin{array}{l}121,000 \\
204, \infty \infty\end{array}$ & ….............. & $\begin{array}{l}265,000 \\
487,000\end{array}$ \\
\hline 1897 & 304,000 & ................. & $210, \infty 00$ & $\cdots$. & 514,000 \\
\hline 1898 & 320,000 & ................... & 362,000 & & $682, \infty \infty$ \\
\hline 1899. & 666,000 & & 360,000 & & $1,026, \infty \infty$ \\
\hline
\end{tabular}

1 Find year for which statistics have been pabliehed.

- Statirtic concerning only the trade with Germany. 


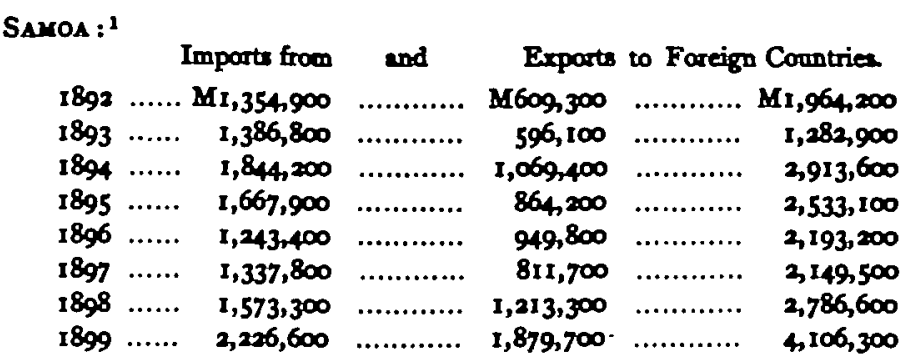

If in all these Protectorates the imports show a larger increase than the exports the principal reason is to be found in the difficulty of opening up the interior for the output of its natural products and the long time needed for the introduction of regular cultivation of the soil. As long as there does not exist a network of railways and steamers bringing the products of the more remote places at very cheap rates to the harbours, and the soil of the colonies cannot be systematically and st:ccessfully worked, the bulk of their trade will always be very limited and not correspond to their size. Every internal war and every failure of crops have exercised an unfavourable influence on the commerce.

The German colonial administration has been endeavouring for some time to better this state of things in the Protectorates. It has constructed roads and bridges and is furthering by all means the shipping to and from the colonies. At the same time lines of telegraph have been established in all African Protectorates and in Deutsch Ost and Sued West Africa, and railways are now being constructed. Other lines for Togo and Kamerun are under consideration, as well as harbours and piers in the chief places. No less effort has been made for the purpose of developing the cultivation of the colonies. By the publication of the results of scientific investigation of their resources and giving privileges and assistance of various kinds, capitalists have been induced to make experiments with the cultivation of tropical plants and to examine the mineral wealth of several Protectorates. While researches of the latter kind are now made in Sued West Africa, Ost Africa, and Neu Guinea, plantations of coffee, cocoa, cotton, etc., have been started in all the tropical colonies.

But all these attempts are not yet finished, and exercise so

1 For Kinatuchou complete untirtic of trade are not available for 1899 . Bolk of trade with Germiny $1900=5,704,000 \mathrm{M}$. 
far only little effect on the bulk of the trade of the German Protectorates. Coffee was exported up to 1899 only from Deutsch Ost Africa and in very small quantities. Cocoa comes only from Kamerun and cotton from Neu Guinea. The following tables show the development of these industries:-

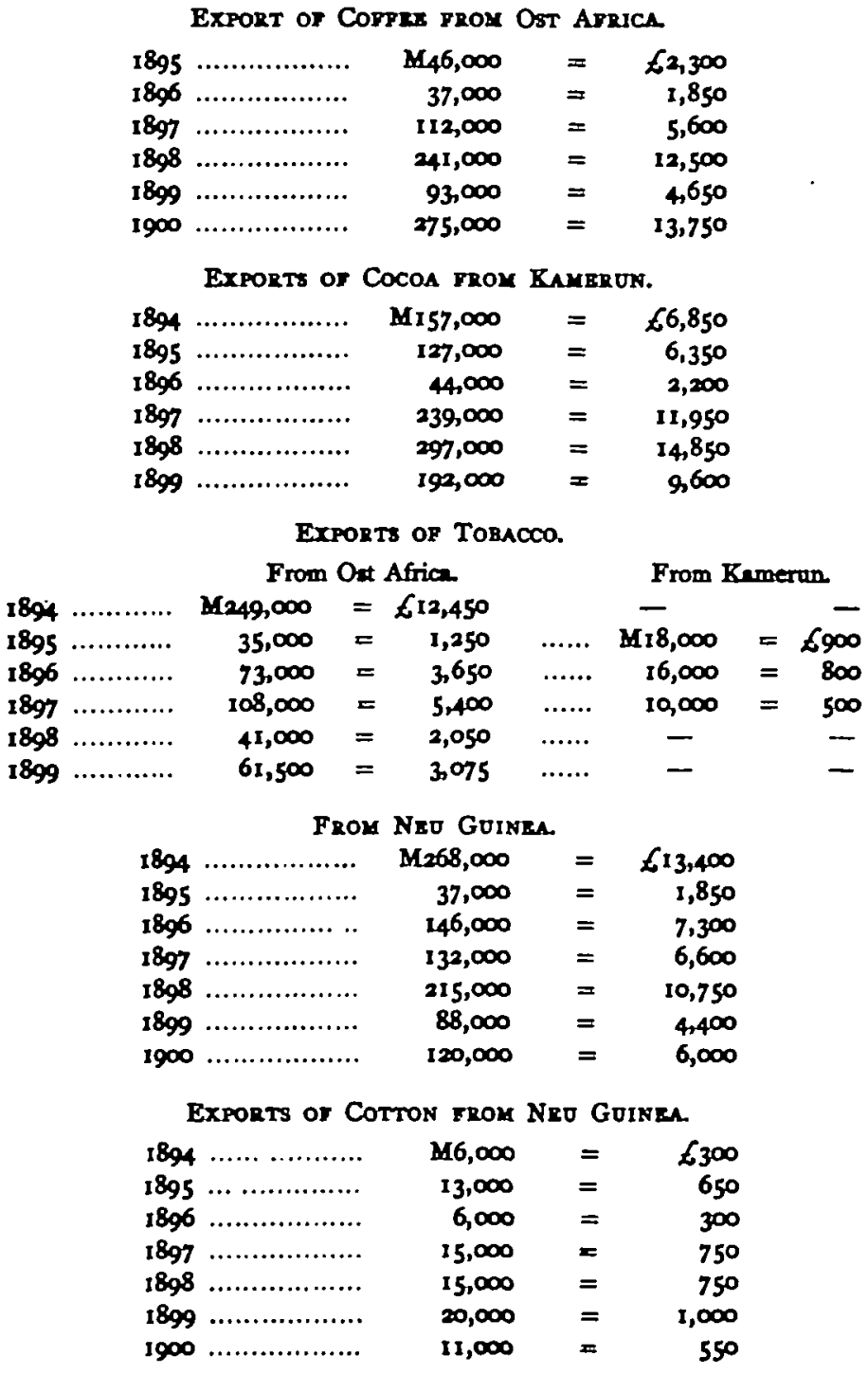


The chief articles of export of the Protectorates are here, as in the British and French West African colonies, the usual African products, as is seen in the following figures :-

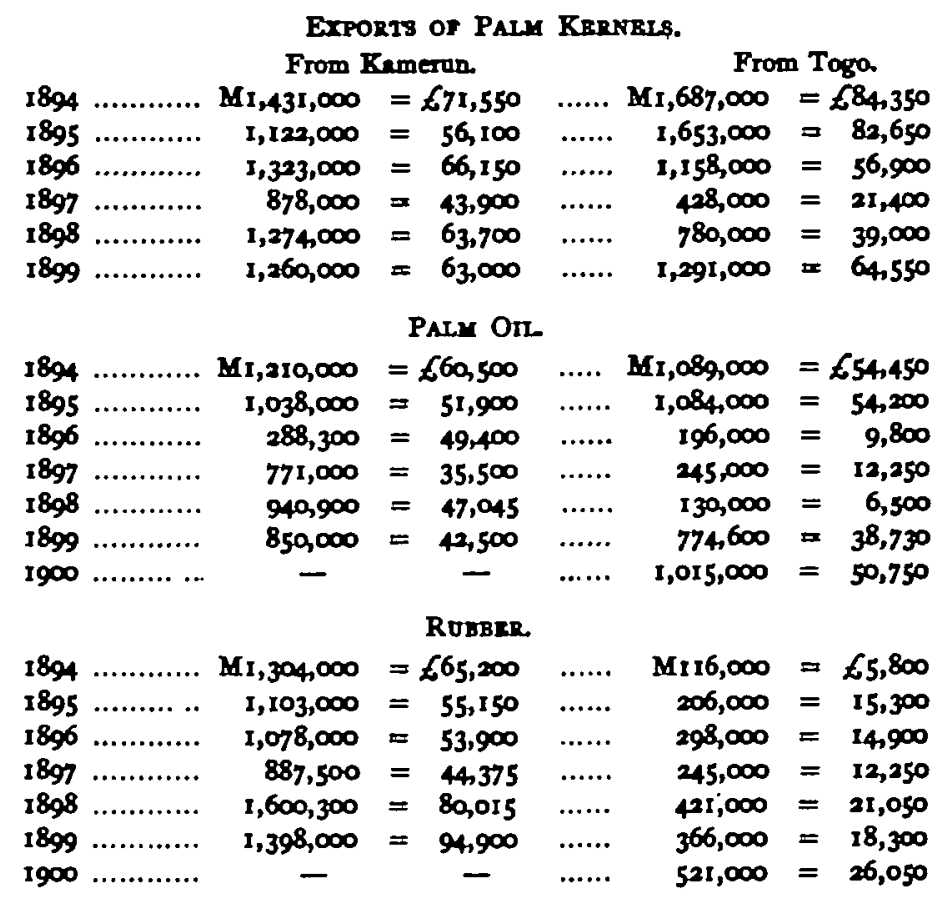

RUBber FBOX Ost ATRICA.

\begin{tabular}{|c|c|c|c|}
\hline $\begin{array}{l}1894 \\
1895 \\
1896\end{array}$ & $\begin{array}{r}M 609,000 \\
772,000 \\
892,000\end{array}$ & $\begin{array}{l}= \\
= \\
=\end{array}$ & $\begin{array}{r}\varangle 30,450 \\
38,600 \\
49,600\end{array}$ \\
\hline 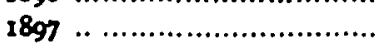 & $1,149,000$ & $=$ & 57,450 \\
\hline 1898 & 970,000 & $=$ & 48,500 \\
\hline 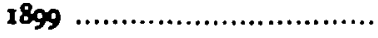 & $1,537,000$ & $=$ & 66,850 \\
\hline 1900 & $1,058,000$ & $=$ & 52,900 \\
\hline
\end{tabular}

ExPORT8 OF Ivory.

From Oxt Africa.

\begin{tabular}{|c|c|c|c|c|c|c|}
\hline & & & & & & \\
\hline & $\mathbf{M}_{2,14}$ & $=t$ & 107,450 & 1... & $\mathrm{M}_{454, \infty}$ & $=£ 27,700$ \\
\hline & 1,42 & $=$ & & $\cdots \cdots$ & & $=29$. \\
\hline & 1,6 & $=$ & & $\cdots$ & 370,000 & $=$ \\
\hline ... & $1,495,000$ & $=$ & & ....... & 534,000 & 26,735 \\
\hline & $1,292, \infty \infty 0$ & $=$ & & ....... & & $=$ \\
\hline & $\alpha$ & & & ....... & $670, \infty 00$ & $=$ \\
\hline & $997, \infty 00$ & $=$ & 79,850 & ....... & - & - \\
\hline
\end{tabular}


Exports of COPRAH.

From Ont Africa.

\begin{tabular}{|c|c|c|c|}
\hline 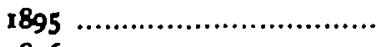 & $\mathbf{M}_{47, \infty}$ & $=$ & $62,45^{\circ}$ \\
\hline $1896 \ldots \ldots \ldots \ldots \ldots \ldots \ldots \ldots \ldots \ldots \ldots \ldots \ldots \ldots \ldots \ldots$ & 103,000 & $x$ & 5,150 \\
\hline 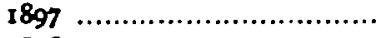 & 205,000 & $=$ & 10,250 \\
\hline 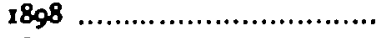 & 314,000 & $=$ & 15,700 \\
\hline 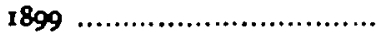 & 108,000 & $=$ & 5,400 \\
\hline 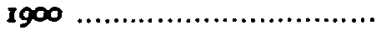 & 210,400 & $=$ & 10,520 \\
\hline
\end{tabular}

ExpoRTS OF COPRAH.

\begin{tabular}{|c|c|c|c|c|c|}
\hline \multirow{3}{*}{$1898 \ldots \ldots \ldots \ldots$} & \multicolumn{2}{|c|}{ From Neu Guinea } & \multicolumn{3}{|c|}{ From Samoe } \\
\hline & M82, $\infty 00$ & $=\zeta_{4}, 100$ & & $\mathbf{M} 2, \infty \infty, \infty \infty$ & $=L_{100,000}$ \\
\hline & 190,000 & 9,500 & ...... & $4,000,000$ & 200,000 \\
\hline …... & 133,000 & 6,650 & ...... & - & - \\
\hline
\end{tabular}

The chief articles of import in the German Protectorates are the same as in all countries undergoing similar development. In the first place may be mentioned textile goods; of no less importance are hardware, engines, provisions. Spirits, arms and gunpowder do not play a less important role in this trade, as is often pretended. The figures for imports for the year 1899 give sufficient proof for this assertion:-

KAMRRON.

\begin{tabular}{|c|c|c|c|c|}
\hline \multicolumn{2}{|c|}{$\begin{array}{l}\text { Total imports ...................... } \\
\text { Imports of textile goods ...... }\end{array}$} & $\begin{array}{r}\text { Mit,133,000 } \\
2,840,000\end{array}$ & $=$ & $\begin{array}{r}6556,600 \\
142,000\end{array}$ \\
\hline ", & herdware ......... & $890, \infty 00$ & $=$ & 44,500 \\
\hline ", & wood $\ldots \ldots \ldots \ldots \ldots \ldots$ & $\begin{array}{l}990,000 \\
936,000\end{array}$ & $\begin{array}{l}= \\
=\end{array}$ & \\
\hline ", & powder ............. & 458,000 & $=$ & \\
\hline ", & $\operatorname{arms} \quad \ldots \ldots \ldots \ldots \ldots$ & $372, \infty 00$ & & \\
\hline
\end{tabular}

Ost AfRica

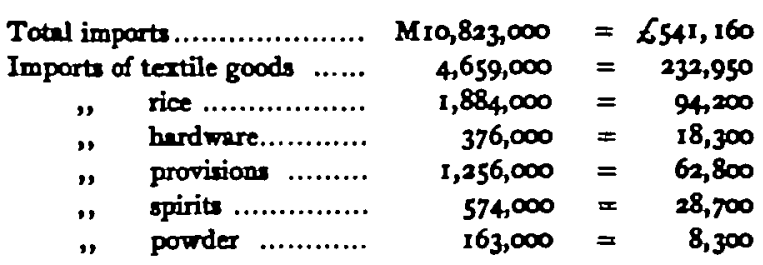


Togo.

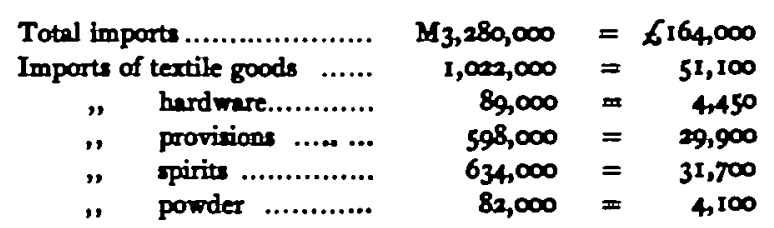

SURD WEST AFrica.

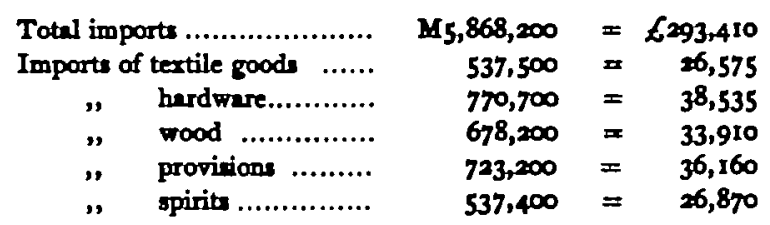

Alfred Zimmerman. 